Journal of Social Sciences 4 (2): 103-110, 2008

ISSN 1549-3652

(C) 2008 Science Publications

\title{
The Influence of Religiosity on Marital Satisfaction
}

\author{
Khodabakhsh Ahmadi, Esfandiar Azad-Marzabadi and Seyed Mahdi Nabipoor Ashrafi \\ The Behavioral Sciences Research Center, Baqiyatallah University, Mollasadra Ave., \\ Vanak Sq P.O. Box: 19945-581, Tehran, 14548, I.R. Iran
}

\begin{abstract}
The following research sought to examine the relationship between a married individual's religiosity level and its impact upon his or her level of marital satisfaction. Findings in this connection can help strengthen families 660 heterosexually hetero-sexually couples from Tehran were studied multistage using cluster sampling. Information regarding religiosity and marital satisfaction was collected using the researcher's prepared questionnaire and ENRICH marital satisfaction scale. The results showed that heterosexually hetero-sexually couples who observe religious beliefs have higher rate of marital satisfaction. Thus, there is a significant correlation between religiosity and marital satisfaction. Considering the relation between religiosity and nine subscales of marital satisfaction, Communication Parenting and religious orientation account for the highest rate of religiosity and sexual relationship accounts for the lowest rate of religiosity. Thus, with the increase in religiosity, marital satisfaction rate will increase and vice versa. It can be concluded that religiosity develops the grounds for marital commitment.
\end{abstract}

Key words: Marital satisfaction, religiosity

\section{INTRODUCTION}

Although previous research supports the existence of a relationship between religiosity and marital satisfaction, relatively little is known about the relationship among various dimensions of the two variables. We already know that stable marriage is associated with improved physical, intellectual, mental and emotional health of men, women and children, as well as equipping them with the values and habits that promote prosperous economic activity ${ }^{[1]}$. Religious practice is also related to positive outcomes for the stability and quality of marriage. ON the other hand numerous sociological studies have shown that valuing religion and regularly practicing it are associated with greater marital stability, higher levels of marital satisfaction and an increased likelihood that an individual will be inclined to marry ${ }^{[2]}$. History bears witness to the antiquity of religiosity. Archaeological and anthropological studies show that religion has always been a part and parcel of human life. Will Durant ${ }^{[1]}$ elieves that religions are so rich, complicated and widespread that they can be traced in all eras of human history. The fact that even a non-religious person may unconsciously refer to God or supernatural powers in time of mental crisis is a proved phenomenon. Frankel, the founder of logo therapy, believes deep and real religious feelings are rooted in the subconscious of each and every human ${ }^{[3,4]}$.

Previous studies have shown that being religious, in the broad sense of the word, can moderate the results of the intense crises of life. Numerous studies on the relation between religion and mental health have been carried out during the past few years, as well. Generally, research has shown that a positive relation between religion and mental health exists ${ }^{[5,6]}$. Therefore, 'spiritual beliefs' can be an interesting issue to fight against problems and various illnesses. Undoubtedly, virtues play an important role in our physical and spiritual health. Same religious beliefs also affect financial management in family so that A study of heterosexually couples with divergent theological views showed that they were more likely to argue, especially about financial matters ${ }^{[7]}$.

Marital satisfaction and satisfaction are two important factors in every marriage. Marital satisfaction is when the couple feels most satisfied with one another ${ }^{[8]}$. In another study which examined the association between religiosity and marital satisfaction among first-married and remarried adults the results show that Religiosity had a significant positive correlation with sexual-satisfaction problems ${ }^{[9]}$. It has

Correspondence Author: Khodabakhsh Ahmadi,The Behavioral Sciences Research Center, Baqiyatallah University, Mollasadra Ave., Vanak Sq. P.O. Box: 19945-581,Tehran, 14548, I.R. Iran 
to be stressed that in Islam has been put too much emphasis on strong and happy marriages. In the holy Qur'an, it has been mentioned that marriages must be based on equality, friendship and love of the couple ${ }^{[10]}$. These factors will lead to a happy marriage ${ }^{[11]}$. Therefore, it is expected that those who are faithful to Islamic values will have more marital adjustability, for religiosity is one of the main pillars of a happy life. One who does not perform his religious duties might as well ignore to perform his marital duties toward his wife and children. According to recent studies, when moral values diminish in a society, promiscuity becomes prevalent; patriarchal ethical values as well as childrearing by both parents gradually vanish and separation, abortion, illegitimate children, prostitution, disloyalty and extramarital relations take over. All these will disintegrate families and lead them to divorce. The relation between religion and marriage has been shown several times through different researches performed. In a research carried out on heterosexually couples who have been married for about 9 years, it was proved that spouses who were committed to performing their religious ceremonies like participation in the Mass, were more satisfied ${ }^{[12]}$. In another research in California, though pale in the first year, religion was proved to have a positive effect on the couple's relationship in the years to come. Nevertheless, more and more research must be done, for different types of marriages can be affected by religion in one way or another ${ }^{[13]}$.In the same research which was about how religiosity helps heterosexually couples Prevent, Resolve and Overcome Marital Conflict the results show that Practitioners may assist religious heterosexually couples that are struggling with marital conflict by encouraging them to look to religious beliefs and practices ${ }^{[14]}$.In another research, Roman Catholic spouses were studied. The heterosexually couples were questioned separately. Each couple believed that religious beliefs will help control the expression of anger and inhibit the desire to retaliate. The relationship with God affected the 'space' in the couple relationship by meeting some of the unmet needs of individuals and by detouring anger away from the spouse to God where it was felt to be safely contained ${ }^{[15]}$. For religious heterosexually couples, the spiritual domain stands alongside biological and systemic domains as an influence upon interaction and mechanism for change. A qualitative methodology consisting of structured interviews of religious spouses was used to investigate effects of prayer on couple interaction during conflict. A reliable description of the dynamics of prayer across spouse interviews was extracted by four analysts using a group interpretive procedure. Findings suggest that prayer invokes a couple-God system, which significantly influences couple interaction during conflict. Overall, prayer appears to be a significant softening event for religious heterosexually couples, facilitating reconciliation and problem solving ${ }^{[16]}$. In another study which represents an attempt to understand the psychological and marital well-being of spouses in mixed-ethnic or faith marriages in terms of the acculturation styles that spouses adopt in adapting to a new cultural environment The study found that the Christian religiosity of the wives was positively statistically significantly related to self-esteem and positive affect and negatively correlated with negative affect, marital satisfaction and marital intimacy ${ }^{[17]}$. Based on the above-mentioned facts and examples, the present study intends to investigate the relation between religiosity and marital satisfaction in each aspect. The main hypothesis of this study is that religious practices influence marital satisfaction.

Sullivan further reported that the wives religious beliefs concerning relational commitment are more important than the husbands' belief in regards to the stability of the marriage. The positive connection between church attendance and lower risk of divorce has been consistently discovered by researchers ${ }^{[13]}$. The researchers reported that people highly committed to a religion have lower divorce rates than low-committed or nonreligious people ${ }^{[18]}$.

In regards to religiosity's impact on intimacy, study of sample of 355 married heterosexually couples shown that higher levels of religiosity were associated with higher ratings of intimacy. This result is consistent with other research linking religiosity and marital satisfaction ${ }^{[19]}$. Overall, religion provides a belief system that supports constructive family behavior and positive family life ${ }^{[20]}$.

It has also been noted that there is a positive link between religious beliefs and behaviors with marital satisfaction and stability ${ }^{[21]}$. Second, religion may emphasize the importance of marriage, thus increasing the commitment heterosexually couples feel toward their marriage ${ }^{[22]}$. According to researches, higher levels of communication skills are associated with increased religiosity in an individual's life ${ }^{[23,24]}$.

\section{MATERIALS AND METHODS}

Target population of this study was selected from The subjects were obtained from a non-clinical populationof Tehran from five different precincts (North, South, East, West and Center). Thirteen hundred and twenty people (660 heterosexually couples) were studied using cluster sampling. In order 


\section{J. Social Sci., 4 (2): 103-110, 2008}

to gather data, ENRICH ${ }^{()}$marital satisfaction scale and the researcher's questionnaire were used. ENRICH'S main test copy includes 115 questions but in this research a 47 item questionnaire was used.

To investigate the influence religiosity had on marital intimacy and satisfaction, the subjects were placed into three groups according to their total score on the Revised Religious Fundamentalism Scale. The groups were categorized as high $(\mathrm{n}=36)$, medium $(n=49)$ and low $(n=38)$.

The Personal Assessment of Intimacy in Relationships (PAIR) is a 36 item selfreport instrument that assesses five types of marital intimacy: emotional, social, sexual, intellectual and recreational ${ }^{[25]}$. The PAIR inventory allows a couple to describe intimacy within their own relationship as they perceive and experience it.

Alport's religious values scale and the religiosity questionnaire were used, too. The questionnaire was prepared by the researchers who had considered religious factors of all sorts. The questionnaire included different aspects like spiritual, materialistic and human values, performance of religious duties, practical belief in observing the Islamic dress code and the performance of the two religious incumbent and abominable precepts. This questionnaire was prepared after content-validity evaluation and construct-validity using internal correlation (coronbach's alpha). The rate of internal correlation was $87 \%$ in this questionnaire. It has to be mentioned that the research data was collected using statistical indices like frequency, percentage, mean, standard deviation and Pearson correlation index, variance analysis test (ANOVA) and (HSD).

\section{RESULT AND DISCUSSION}

1320 people (660 hetro-sexually couples) were studied in this research. The average age of men was $37.8 \pm 5.4$ and that of women was 33.8 \pm 5.6 . Educationwise, about $62 \%$ of men were holders of an associate's degree or higher and about $73 \%$ of women were holders of a high school diploma or lower. They all lived $10.95 \pm 6.05$ years together, the time gap between their engagement and marriage was $8.55 \pm 0.7$ years, their engagement length was $1.4 \pm 0.49$ years and the age gap between the heterosexually couples was $4.26 \pm 3.6$ years. $47.5 \%$ of the heterosexually couples considered themselves as very or extremely religious, $49.7 \%$ as average and $2.3 \%$ as 'a little' religious. The comparative study of these statistics using Mann Whitney's test did not show a significant difference between men and women (Table 1).
Table 1: Religiosity rate in the study groups

\begin{tabular}{llr}
\hline Religiosity rate & Prevalence & Percentage \\
\hline Low & 31 & 2.3 \\
Medium & 657 & 49.7 \\
High & 627 & 47.5 \\
No answers & 7 & 0.5 \\
Total & 1320 & 100.0 \\
\hline
\end{tabular}

Table 2: Marital satisfaction

\begin{tabular}{llc}
\hline Satisfaction status & Prevalence & Percentage \\
\hline Strong dissatisfaction & 48 & 3.6 \\
Dissatisfaction & 146 & 11.1 \\
Moderate (borderline) & 659 & 49.9 \\
Satisfied & 381 & 28.9 \\
Very satisfied & 78 & 5.9 \\
No answers & 8 & 0.6 \\
Total & 1320 & 100.0
\end{tabular}

Table 3: Mean and standard deviation in four study groups

\begin{tabular}{llll}
\hline Groups & Count & Mean & SD \\
\hline A little religiosity & 31 & 160 & 30.8 \\
Average religiosity & 683 & 177 & 29.5 \\
Much religiosity & 495 & 190 & 29.6 \\
Too much religiosity & 114 & 197 & 30.7 \\
\hline
\end{tabular}

Table 4: Variance analysis test results of marital satisfaction in four study groups

\begin{tabular}{llllll}
\hline Source & SS & F. & Mean squares & 'F' ratio & F prob \\
\hline Between groups & 86620 & 3 & 28873.6 & 32.78 & 0.0001 \\
Within groups & 1122047 & 1274 & 880.7 & & $* *$ \\
Total & 1208668 & 1277 & & & \\
\hline
\end{tabular}

Religiosity as measured by the Revised RF Scale alone shows no statistically significant relationship with marital intimacy and satisfaction. Gender and religiosity do correlate when measuring marital intimacy and marital satisfaction.

The marital satisfaction status of the heterosexually couples showed $3.6 \%$ of 'strong dissatisfaction, $11.1 \%$ of dissatisfaction, $49.9 \%$ moderate (borderline), $28.9 \%$ satisfied and $5.9 \%$ very satisfied'. Meanwhile, $0.6 \%$ did not score at all. (Table 2)

(ANOVA) or variance analysis test was used to study the role of religiosity in marital satisfaction. The total marital satisfaction in four religious groups (a little, average, much and too much religiosity) shows $\mathrm{F}_{\mathrm{p}[\alpha<0.01]}>\mathrm{FR}$ and thus the difference between these four groups at the level of $\alpha<0.01$ is statistically significant. (Table 3 and 4) To determine the difference, the statistical HSD was used, in which the differences are one-to-one in average groups. The one-to-one comparison of the four groups' average showed that all of them enjoy a significant difference at the level of $\alpha \leq 0.01$. (Table 5).

The significance of this comparison shows that the marital satisfaction rate among the very religious 
groups is higher than among those who enjoy a little religiosity. Therefore, marital satisfaction is at its highest among very religious ones and at its lowest among less religious groups.

The nine-item study of marital satisfaction in four groups of religiosity (a little, average, much, too much) was carried out using (ANOVA) variance analysis method. A significant difference of $\alpha \leq 0.01$ was seen in all factors including Personality Issues, Communication, Conflict Resolution, Financial Management, Sexual Relationship, Friends and Family, Leisure Activities, Parenting and Religious Orientation.

To determine the differences, a one-to-one comparison of mean in four groups was rendered using (HSD'S test). The results showed that in all factors mentioned above there is a significant difference in the mean of all four groups (Table 6).

As the research hypothesis and the effects of religiosity on marital satisfaction were proved, the rate of this relation using correlation index was studied. The correlation indices are shown in Table 7. As can be noticed, religiosity shows a significant association with the studied items: 0.29 with communication, 0.26 with parenting and religious orientation, 0.24 with leisure activities, 0.23 with personality issues and friends and family, 0.22 with conflict resolution, 0.21 with financial management and 0.17 with sexual relationship. The very existence of a positive, significant relation shows that with the increase of religiosity in heterosexually couples, the marital satisfaction increases, as well. Univariate two-way analysis of variance (ANOVA) was conducted on Sexual Intimacy for effects due to gender, religiosity group and the interaction of gender by religiosity group.

This quantitative study sought to discover the influence religiosity has upon a married individual's

\begin{tabular}{lllll}
\multicolumn{5}{c}{ Table 5: HSD's test results of marital satisfaction in four study groups } \\
\hline $\mathrm{I}$ & $\mathrm{j}$ & $\mathrm{i}-\mathrm{j}$ & $\mathrm{SD}$ & Sig. \\
\hline 1 & 2 & -17.01 & 5.46 & 0.0020 \\
1 & 3 & $-29.98^{*}$ & 5.49 & 0.0001 \\
1 & 4 & $-37.34^{*}$ & 6.01 & 0.0001 \\
2 & 3 & -12.98 & 1.78 & 0.0001 \\
2 & 4 & -20.33 & 3.02 & 0.0001 \\
3 & 4 & -7.35 & 3.08 & 0.0170 \\
\hline
\end{tabular}

Table 6: Religiosity and its relation with marital satisfaction

\begin{tabular}{|c|c|c|c|c|c|c|c|}
\hline Marital satisfaction subscale & Groups & Count & Mean & $\mathrm{SD}$ & 'F' ratio & F prob & HSD based difference \\
\hline \multirow[t]{4}{*}{ Personality issues } & Little religiosity & 31 & 3.27 & 0.97 & 21.99 & $<0.001$ & \\
\hline & Average religiosity & 638 & 3.84 & 0.85 & & & \\
\hline & Much religiosity & 495 & 4.14 & 0.81 & & & \\
\hline & Toomuch religiosity & 114 & 4.22 & 0.87 & & & $1<2<3$ and 4 \\
\hline \multirow[t]{4}{*}{ Communication } & Little religiosity & 31 & 3.35 & 0.52 & 24.87 & $<0.001$ & \\
\hline & Average religiosity & 638 & 3.73 & 0.79 & & & \\
\hline & Much religiosity & 495 & 4.03 & 0.77 & & & \\
\hline & Too much religiosity & 114 & 4.21 & 0.81 & & & $1<2<3<4$ \\
\hline \multirow[t]{4}{*}{ Conflict resolution } & Little religiosity & 31 & 3.37 & 0.89 & 19.82 & $<0.001$ & \\
\hline & Average religiosity & 638 & 3.54 & 0.87 & & & \\
\hline & Much religiosity & 495 & 4.84 & 0.83 & & & \\
\hline & Toomuch religiosity & 114 & 4.05 & 0.89 & & & 1 and $2<3<4$ \\
\hline \multirow{4}{*}{ Financial management } & Little religiosity & 31 & 3.30 & 0.64 & 16.38 & $<0.001$ & \\
\hline & Average religiosity & 638 & 3.72 & 0.89 & & & \\
\hline & Much religiosity & 495 & 3.98 & 0.91 & & & \\
\hline & Toomuch religiosity & 114 & 4.16 & 0.90 & & & $1<2<3$ and 4 \\
\hline \multirow{4}{*}{ Leisure activities } & Little religiosity & 31 & 3.43 & 0.71 & 23.93 & $<0.001$ & \\
\hline & Average religiosity & 638 & 3.79 & 0.66 & & & \\
\hline & Much religiosity & 495 & 4.06 & 0.71 & & & \\
\hline & Toomuch religiosity & 114 & 4.15 & 0.67 & & & $1<2<3$ and 4 \\
\hline \multirow[t]{4}{*}{ Sexual relationship } & Little religiosity & 31 & 3.48 & 0.44 & 12.64 & $<0.001$ & \\
\hline & Average religiosity & 638 & 3.62 & 0.68 & & & \\
\hline & Much religiosity & 495 & 3.82 & 0.69 & & & \\
\hline & Toomuch religiosity & 114 & 3.92 & 0.82 & & & 1 and $2<3$ and 4 \\
\hline \multirow[t]{4}{*}{ Parenting } & Little religiosity & 31 & 3.35 & 0.96 & 29.41 & $<0.001$ & \\
\hline & Average religiosity & 638 & 3.43 & 0.73 & & & \\
\hline & Much religiosity & 495 & 4.04 & 0.77 & & & \\
\hline & Toomuch religiosity & 114 & 4.29 & 0.80 & & & $1<2<3<4$ \\
\hline \multirow[t]{4}{*}{ Friends and family } & Little religiosity & 31 & 3.49 & 0.81 & 21.10 & $<0.001$ & \\
\hline & Average religiosity & 638 & 3.82 & 0.70 & & & \\
\hline & Much religiosity & 495 & 4.08 & 0.72 & & & \\
\hline & Toomuch religiosity & 114 & 4.21 & 0.72 & & & $1<2<3$ and 4 \\
\hline \multirow[t]{4}{*}{ Religious orientation } & Little religiosity & 31 & 3.73 & 0.87 & 27.42 & $<0.001$ & \\
\hline & Average religiosity & 638 & 4.19 & 0.74 & & & \\
\hline & Much religiosity & 495 & 4.46 & 0.69 & & & \\
\hline & Toomuch religiosity & 114 & 4.63 & 0.58 & & & $1<2<3<4$ \\
\hline
\end{tabular}




\section{J. Social Sci., 4 (2): 103-110, 2008}

Table 7: Correlation between religiosity and marital satisfaction

\begin{tabular}{lll}
\hline Factors & Correlation Rate & $\mathrm{p}$-value \\
\hline General satisfaction & 0.29 & $<0.001$ \\
Personality Issues & 0.23 & $<0.001$ \\
Communication & 0.26 & $<0.001$ \\
Conflict Resolution & 0.22 & $<0.001$ \\
Financial management & 0.21 & $<0.001$ \\
Leisure activities & 0.24 & $<0.001$ \\
Sexual Relationship & 0.17 & $<0.001$ \\
Parenting & 0.26 & $<0.001$ \\
Friends and Family & 0.23 & $<0.001$ \\
Religiosity Orientation & 0.26 & $<0.001$ \\
\hline
\end{tabular}

marital intimacy level and his or her marital satisfaction. The subject's religiosity level was measured by the Revised Religious Fundamentalism Scale; marital intimacy was measured by the Personal Assessment of Intimacy in Relationships, while marital satisfaction was measured by the Dyadic Adjustment Scale. A one-way ANOVA and a two-way ANOVA on each variable was conducted to discover any statistically significant relationship between the variables.

This study appeared to correlate with the findings of others where no significant relationship was found between religiosity and marital satisfaction ${ }^{[19]}$. However, this study did not confirm the findings of others in which the researchers found that higher religiosity is associated with higher ratings of intimacy. In fact, this study did not discover any significant relationship between religiosity and intimacy. The reason for this result may be attributed to the difference in the study designs ${ }^{[26]}$.

Since this sample was a homogenous sample, it could be implied that this factor alone resulted in the high mean scores.

Equality is one of the most significant factors in choosing a future spouse. Equality means harmony and sameness in status and rank in a boy and a girl. Simply it means spouses match each other. The more the level of equality, harmony and sameness, the stronger the marriage. The most important element in equality in a boy and a girl is the sameness of religion. The other studies shows that the highest rate of marital satisfaction has been seen in heterosexually couples who enjoy harmony in their life philosophy, their assumptions of sexual satisfaction, the amount of time they spend together and the way they spend their leisure time $^{[27,28]}$.

According to the Holy Qur'an's verses, family columns can be divided into: Equality, Solace, Friendship, Good behavior, Justice, Divine bond and Chastity ${ }^{[10]}$.

In the introduction of the constitution of the Islamic Republic of Iran it has been stated that: The family is the fundamental unit of society and the main center of growth and transcendence for humanity and the provision of the possibility for achieving this purpose is the responsibility of the Islamic government. Considering that the family is the fundamental unit of the Islamic society, all relevant laws, regulations and planning provisions must serve the purpose of facilitating the establishing of families and safeguarding the sacredness of the family institution and strengthening family relations on the basis of Islamic law and ethics.

Happy and satisfied heterosexually couples are those who have lots in common, who are happy with their kind and level of their relations, who are happy with the way they pass their leisure time and are those who are good financial managers. Here religiosity is one of the main columns of happiness. Correlate study provides strong evidence that, among a large sample of Kuwaiti Muslim undergraduate students, religious people are happier ${ }^{[29]}$. He who does not observe his religious duties may disregard his wife and married life as well. In the holy Qur'an, it has also been stated that A pious man should marry a virtuous woman'. The results of many researches prove the fact that heterosexually couples' equality in religious beliefs, faith and piety are the main factors for a happy marriage ${ }^{[10]}$.

If we consider all these narrations closely, especially the results of the present study we can see that the role of religiosity and marital satisfaction has once more been emphasized. The religiosity factors studied in this research were: faith in God, faith in afterlife, belief in moral values and performance of the obliged duties and the observing of the Islamic dress code. Undoubtedly, for God's believers and those who follow the Islamic law and sharia, religiosity is the main factor in choosing their future spouse. These people protect their looks, observe the Islamic dress code, Hijab, (the three main factors in moral deviation), consider their spouse as a subject of Allah and prevent oppressing him/her, observe hygiene principles and treat their spouse honestly and gently, even in sexual relationship, they always consider Allah. Therefore, it is truly expected that the rate of marital satisfaction be higher among religious people. In this relation, a few items have to be pointed out:

- In addition to the fact that religious studies are important for all happy marriages, it was concluded that extremely religious people were more adjustable in their marriage than religious ones; and the religious ones were more adjustable than those in an average group. The same way, those 


\section{J. Social Sci., 4 (2): 103-110, 2008}

with an average level of religiosity have higher marital adjustability than those with a little religiosity. Therefore, one's commitment to religious laws and his mental growth are two main factors in the relation between religiosity and marital satisfaction.

- It was concluded that religiosity has a great role in all aspects of marital satisfaction. Marital satisfaction can be evaluated on the basis of 10 items. In the present study, the 'equality aspect of men and women' was left out and the other nine items were studied. In all these 9 items, there was a significant difference between the level of religiosity and marital satisfaction ${ }^{[30]}$.

- The rate and intensity of religiosity and marital satisfaction was between $0.17-0.29$. This rate was 0.29 in Communication, 0.26 in Parenting and of Religious Orientation, 0.24 in Leisure Activities, 0.23 in Personality Issues and Friends and Family, 0.22 in Conflict Resolution and 0.17 in Sexual Relationship. All the coefficients were statistically positive and significant. Based on these conclusions, it can be said that religiosity, in the first place, improves and reinforces the couple's relationship, elevates parental duties and helps them use proper methods to educate their children. Furthermore, parents can establish proper relations with their children and help develop common philosophical goals and viewpoints with each other to reach a better married life. In the second place, stands togetherness of the heterosexually couples which rises from religiosity and helps them plan their leisure activities more effectively. In the third place, religiosity helps people adjust with each other's tastes and establish proper relations with their friends and relatives. In the fourth place, the couple will be able to solve their problems in the best way possible and to plan for their salaries and expenses. In the fifth place, the sexual relations of the couple will be satisfactory for both sides.

- Sexual Relationship with 0.17, Financial Management with 0.21 and Conflict Resolution with 0.22 holds the lowest rank in the relation between religiosity and marital satisfaction. Lack or non-existing dissemination of Islamic viewpoints in regard to sexual relationship, conflict resolution methods and financial management among the public are the main reasons for the above-mentioned facts and figures. Apparently, practical work in personal behavior, mutual relations, child education, family care and familial relation from the religion's viewpoint are carried out quite easily. While issues like sexual relations, financial management and problem-solving are dealt with so slowly and at only a general level. Islamic society, especially at present, needs deep and extensive dialogs over sex issues, family financial problems and problem-solving methods from the Islamic viewpoint. Therefore, we suggest that Islamic, research and scientific centers seriously plan programs in regard to family and family relations.

It has to be noted that the results of the present research along with the rest of the researches mentioned in the introduction prove the relation between religiosity and marital satisfaction. However, there are studies which report vague and insignificant association between religiosity and marital satisfaction. For example in the similar research in which Data from married heterosexually couples were analyzed to isolate aspects of religiosity that predicted each of four dimensions of marital satisfaction. Religious ritual, experience and, to a lesser extent, belief correlated significantly with the dimensions of marital satisfaction, even when controlling for marital conventionality $^{[31]}$. Therefore, considering the results of the present study and other researches in this field, the following can be suggested:

- Religiosity level of people can be considered as one of the predictive criteria for a successful marriage.

- Religiosity can be a useful criterion is choosing a spouse.

- The reinforcement of religious beliefs can be a way of preventing marital malsatisfactions as well as a good method for dealing with dissatisfactions.

- The Islamic viewpoints on all aspects of marital satisfaction, especially on sexual relations with a spouse, financial management and conflict resolution' should all be vastly collected and published for the public.

- Research on this issue should be expanded especially when the effect of a fall in religiosity after marriage and the impact of religious differences among the heterosexually couples will surely affect the marital adjustability of the spouses.

\section{REFERENCES}

1. Waite, L. and M. Gallagher, 2000. The Case for Marriage: Why Married People Are Happier, Healthier and Better Off Financially. Doubleday, New York. 
2. Weaver, A.J., J.A. Samford, V.J. Morgan, D.B. Larson, H.G. Koenig and K. J,Flannelly, 2002. A systematic review of research on religion in six primary marriage and family journals: 19951999. Am. J. Family Ther., 30: 293-309.

3. Durant, W., 1926. The Story of Philosophy. Simon and Schuster, New York.

4. Durant, Will (2001). Heroes of History: A Brief History of Civilization from Ancient Times to the Dawn of the Modern Age. New York: Simon and Schuster pub.

5. Grom, B., 2000. Religiosity and subjective wellbeing. Psychother. Psychosom. Med. Psychol., 50: 187-192.

6. Abdel-Khalek, A.M., 2008 Religiosity, health and well-being among Kuwaiti personnel. Psychol. Rep., 102: 181-184.

7. Büssing Arndt, Ostermann Thomas and Matthiessen Peter F.' The Role of Religion and Spirituality in Medical Patients in Germany, Journal of Religion and Health, Volume 44, Number 3 / September, 2005, P: 321-340.

8. Sinha, P. and N. Mukerjec, 1990. Marital satisfaction and space orientation. J. Soc. Psychol., 130: 633-639.

9. Orathinkal, J. and A. Vansteenwegen, 2006. Religiosity and Marital Satisfaction. Contemporary Family Ther., 28: 497-504.

10. Yusuf Ali's translation of the meanings of the Holy Qur'an, Index in Arabic by Muhammed Fuad Abdul Baqi. Cairo: Dar Al-Fikr. 1406 (1986). The Arabic Title of the index is: "Al-Mu'ajam AlMufahras Li Alfadh Al-Qur'an Al-Kareem." Chapter 30, verse 21; Chapter 4, verse 20, 59; Chapter 2, verse 23; Chapter 49, verse 49.

11. Bradbury, T.N., F.D. Fincham and S.R.H. Beach, 2000. Research on the nature and Determinants of marital satisfaction. J. Marriage Family, 62: 964-980.

12. Fieses, B.H. and T.J., Tomcho, 2001. Finding in religious practices: The relation between religious holiday rituals and marital satisfaction. J. Family Psychol., 15: 597-609.

13. Sullivan, K.T., 2001 Understanding the relationship between religiosity and marriage: An investigation of the immediate and longitudinal effects of religiosity on newlywed heterosexually heterosexually couples. J. Family Psychol., 15: 610-626.
14. Lambert, N.M. and D.C. Dollahite, 2006. How religiosity helps heterosexually heterosexually couples prevent, resolve and overcome marital conflict. Family Relat., 55: 4, 439-449.

15. Marsh, R. and R. Dallos, 2001. Roman Catholic heterosexually heterosexually couples: Wrath and religion. Family Process. Fall, 40: 343-360.

16. Butler, M.H., B.C. Gardner and M.H. Bird, 1998. Not just a time-out: Change dynamics of prayer for religious heterosexually heterosexually couples in conflict situations. Family Process. Winter, 37: 451-478.

17. Rayya Abu, Motkal Hisham, Acculturation, Christian religiosity, and psychological and marital well-being among the European wives of Arabs in Israel,Journal of Mental Health, Religion \& Culture, Volume 10, Number 2, March 2007 , pp. 171-190(20)

18. Spilka, B., R.W. Hood and R.L. Gorsuch, 1985. The Psychology of Religion: An Empirical Approach. Prentice-Hall, Englewood Cliffs, NJ. ISBN: 0-13-736398-2, Description: Hardcover, xii +388 pages.

19. Feeney, J.A., P. Noller and C. Ward, 1997. Marital satisfaction and spousal interaction. In: Satisfaction in Close Relationships, Sternberg, R.J. and M. Hojjat (Eds.). Guilford, New York, pp: 160-189.

20. Thomas, A.L. and M. Cornwall, 1990. Religion and family in the 1980s: Discovery and development. J. Marriage Family, 52: 983-992.

21. White, L.K. and A. Booth, 1991. Divorce over the life course: The role of marital happiness. J. Family, 12: 5-21.

22. Larson, L.E. and J.W. Goltz, 1989. Religious participation and marital commitment. Rev. Relig. Res., 30: 387-399.

23. Mahoney, A., K.I. Pargament, N. Tarakeshwar and A.B. Swank, 2001. Religion in the home in the 1980's and 1990s: A meta-analytic review and conceptual analysis of links between religion, marriage and parenting. J. Family Psychol., 15: 559-596.

24. Hossain, M.S. and M.Z. Siddique, 2008. Does religiosity help Muslims adjust to death?: A research note. Omega (Westport), 57: 113-119. 
25. Schaefer, M.T. and D.H. Olson, 1981. Assessing intimacy: The PAIR inventory. J. Marital Family Ther., 47-60.

26. Schumm, W.R., G.J. Jeong. and B. Silliman, 1990. Protestant fundamentalism and marital success revisited. Psychol. Rep., 66: 905-906.

27. Kaslow, F.W., 1998. The Handbook Of Relational Diagnosis and Dysfunctional Family Patterns. Wiley, New York.

28. Kuehlwein, K.T. and D.I. Gottschalk, 2000. Legal and Psychological Issues Confronting Lesbian, Bisexual and Gay Couples and Families. In: Handbook of Couple and Family Forensics: A Sourcebook for Mental Health and Legal Professionals, Kaslow, F. (Ed.). John Wiley, New York, pp: 164-187.
29. Abdel-Khalek, A.M., 2005. Happiness, health and religiosity: Significant relations. Mental Health Relig. Cult., 9: 85-97.

30. Foweres, B.J. and D.H. Olson, 1989. ENRICH martial inventory. A Discriminant validity and cross validation assessment. J. Marital Family Ther., 15: 65-79.

31. Wilson, M.R. and E.E. Filsinger, 1986. Religiosity and marital satisfaction: Multidimensional interrelationships. J. Marriage Family, 48: 147-51. 